\title{
Ольга ТАБАКА,
}

orcid.org/0000-0001-5496-7098

аспірантка кафедри загальної педагогіки та дошкільної освіти Дрогобицького державного педагогічного університету імені Івана Франка (Дрогобич, Львівська область, Україна) o.m.tabaka@gmail.com

\section{РОЗВИТОК МОВЛЕННЯ ДОШКІЛЬНЯТ: АКТУАЛЬНІ ПРОБЛЕМИ, ШЛЯХИ РОЗВ’ЯЗАННЯ}

У статті проаналізовано актуальні питання розвитку мовлення дітей дошкільного віку. Констатовано роль мовлення в житті людини. Доведено важливість інтенсифікації розвитку мовлення в дошкільному дитинстві. Аналіз основних положень Базового компонента дошкільної освіти дозволив визначитися з основною категорією - мовленнєвою компетентністю, а також з'ясувати ії складові частини. Мовленнєва компетентність - це здатність дитини продукувати свої звернення, думки, враження тощу в будь-яких формах мовленнєвого висловлювання за допомогою вербальних і невербальних засобів. Структуру мовленнєвої компетентності складають взаємопов'язані між собою фонетичний, лексичний, граматичний, діалогічний, монологічний складники.

Вивчення наукових джерел дало змогу констатувати недостатній рівень розвитку мовлення дітей дошкільного віку. Установлено, щчо причинами такого стану речей є погіршення стану здоров'я дошкільників, звуження обсягу їхнього «живого» спілкування з батьками й родичами. Свою роль відіграє й орієнтація вихователів на середній рівень мовленнєвого розвитку вихованців, використання в роботі з ними фронтальних методів.

Аналіз наукових джерел дозволив виокремити шляхи подолання проблем у розвитку мовлення дошкільнят. До них, зокрема, належать: надання дитині дошкільного віку можливості отримувати власний комунікативномовленнєвий розвиток, розширення кола й інтенсивності ї̈ спілкування тощчо. Доведено необхідність удосконалення та роботи педагогічних працівників закладів дошкільної освіти, а також методичного супроводу їхньоі діяльності. Така робота має бути комплексною та систематичною. В ї̈ основі мають лежати вдосконалені програми з навчання мови й розвитку мовлення дітей. Вихователі мають прагнути до урізноманітнення форм, методів і засобів навчання дітей рідної мови й розвитку культури мовлення тощзо. Усе ие створить умови для подолання проблем, з якими стикаються сучасні дошкільнята в процесі мовленнсвого розвитку.

Ключові слова: мовлення, мова, мовленнєва компетентність, дитина дошкільного віку.

\section{Olha TABAKA, orcid.org/0000-0001-5496-7098 Postgraduate Student at the Department of General Pedagogy and Preschool Education Drohobych Ivan Franko State Pedagogical University (Drohobych, Lviv region, Ukraine) o.m.tabaka@gmail.com}

\section{SPEECH DEVELOPMENT OF PRESCHOOL CHILDREN: CURRENT PROBLEMS, WAYS OF SOLUTION}

The topical issues of speech development of preschool children are analyzed in this article. The role of speech in human life is stated. The importance of intensification of speech development in preschool childhood is proved. The analysis of the substantive provisions of the Basic Component of preschool education allowed to determine the basic category: speech competence, as well as to clarify its components. Speech competence is the ability of a child to produce his / her appeals, thoughts, impressions, etc. in any form of speech through verbal and nonverbal means. The structure of speech competence includes interconnected phonetic, lexical, grammatical, dialogical, monologue components.

The study of scientific sources made it possible to state the insufficient level of speech development of preschool children. It is established that the reasons for this state of affairs are the deterioration of the health of preschoolers, the narrowing of their "live" communication with parents and relatives. The orientation of teachers on the average level of speech development of pupils, the usage of frontal methods in work with them also plays its role.

The analysis of scientific sources allowed us to identify ways to overcome speech development problems of the preschool children. These include, in particular, giving the preschool child the opportunity to receive his/her own communicative and speech development, expanding the range and intensity of its communication, and so on. The necessity of improvement and work of pedagogical workers of preschool educational establishments, and also methodical support of their activity is proved. Such work should be complex and systematic. It should be based on improved programs of language learning and speech development for children. The teachers should strive to diversify the forms, methods and means of teaching children their native language and the development of speech culture, etc. All this will create conditions for overcoming the problems faced by modern preschoolers in the process of speech development.

Key words: speech, language, speech competence, preschool child. 
Постановка проблеми. У всі часи ті, хто мали дотичність до дошкільного дитинства, одним із-поміж головних завдань освіти та виховання визначали розвиток мовлення дітей. Багато науковців та педагогів називають його ведучим, вирішальним, пріоритетним у розвитку та становленні особистості.

Саме мовлення $\epsilon$ тим важливим досягненням дитини, яке дозволяє їй входити у світ, пізнавати його і себе у ньому. За допомогою мовленнєвої діяльності малюк здатен чути і розуміти тих, хто поруч, може спілкуватися, виявляти свої бажання та наміри, бути прийнятим і активним в ігровій діяльності, яка $є$ ведучою у цьому віковому періоді, а також успішно підійматися сходинками, що приведуть до навчання у школі. Зрештою, мова, мовлення - це той дар, який має лише людина та який дозволяс їй ставати людиною, не просто істотою, а людиною, яка володіє словом і повинна використовувати його, на думку Я. Коменського, для ближнього.

Оскільки дошкільний вік є сензитивним і надто важливим для розвитку мовлення, то це підкреслює відповідальність педагогів, які працюють 3 малюками. Розвинути мовлення - це означає працювати над усіма його сторонами: фонетичною, лексичною, граматичною та діамонологічною компетенціями, а також над формуванням комунікативних умінь та навичок. Перед педагогами постають важливі завдання - забезпечення умов, які б сприяли успішному мовленнєвому розвитку та пошук найефективніших шляхів виховання мовленнєвої особистості дошкільників.

Однак вивчення теорії та практики дошкільної освіти дозволяє констатувати певні труднощі в розвитку мовлення дошкільнят, що спонукає до грунтовнішого дослідження означеної проблеми.

Аналіз досліджень. Варто зазначити, що проблема розвитку мовлення дітей дошкільного віку стала предметом досліджень низки науковців, зокрема А. Богуш, Н. Гавриш, Л. Іщенко, Т. Котик, Т. Піроженко, А. Самохвалової та інших. Автори доводять необхідність інтенсивного розвитку мовлення дошкільнят, вказують на особливості цього процесу. Важливою метою їхніх розвідок став пошук шляхів оптимізації роботи 3 розвитку мовлення дошкільнят. Автори виступають прихильниками цілісного підходу до формування мовно-мовленнєвої компетенції як одного з ключових критеріїв і водночас вагомої умови становлення та розвитку мовленнєвої особистості дошкільника (Базовий компонент, 2021).

Мета статті - на основі вивчення наукової літератури з'ясувати можливі проблеми у розви- тку мовлення дітей дошкільного віку, а також вказати шляхи їхнього подолання.

Виклад основного матеріалу. Нова редакція Базового компонента дошкільної освіти (2021р.) (далі - БКДО) розглядає розвиток мовлення як один із основних освітніх напрямів, вважаючи, що саме він $є$ важливим підгрунтям для формування мовної та мовленнєвої компетентності дошкільника. Документ визначає мовленнєву компетентність як здатність дитини продукувати свої звернення, думки, враження тощо в будьяких формах мовленнєвого висловлювання за допомогою вербальних і невербальних засобів. Мовленнєва компетентність об'єднує фонетичний, лексичний, граматичний, діалогічний, монологічний складники та засвідчує їх взаємозалежність і взаємозумовленість. Стандарт акцентує не на розв'язанні окремих завдань мовленнєвого розвитку дітей, а на цілісному підході до формування мовленнєвої компетентності (в єдності iї складників) як одного 3 ключових критеріїв i водночас вагомої умови становлення й розвитку мовленнєвої особистості дошкільника, що відбувається на етапі дошкільного дитинства.

У Методичних рекомендаціях до БКДО йдеться про те, що створення дитиною різних форм висловлювання $\epsilon$ індивідуальним процесом продукування нею мовлення, що передбачає: iї намір сказати своє слово, саму суть думки дитини, відбір вербальних і невербальних засобів для іiї словесного оформлення, процес озвучування задуманого, контроль за сказаним і виправлення при потребі.

Методичні рекомендації підкреслюють, що педагогам і батькам важливо усвідомити, що розвиток мовлення дитини відбувається не лише шляхом наслідування мовлення інших людей, а й завдяки активній мовленнєвій практиці, власному досвіді використання мовлення в різних життєвих ситуаціях. Тому дошкільнята повинні мати можливість набувати таку практику повсякчас, чому сприятиме діалоговий формат міжособистісної взаємодії дитини з педагогом і ровесниками.

Визначення мовленнєвої компетентності дошкільників, яке подається в Стандарті, наголошує на невід'ємній цілісності й взаємозалежності, взаємопов'язаності таких складників, як фонетичний, лексичний, граматичний, діалогічний і монологічний. Це означає, що формування відповідних умінь має відбуватися не формально, а бути присутнім в різних формах і видах мовленнєвої комунікації. Важливо розуміти, що занепад будь-якого з них може спричинити низький рівень мовленнєвого розвитку, ускладнення становлення мовленнєвої компетентності. У Методичних реко- 
мендаціях наголошується, що лише комплексний підхід до реалізації всіх завдань мовленнєвого розвитку дає можливість успішно виконувати завдання означеного освітнього напряму Стандарту. Наступний важливий наголос зроблено на комунікативній спрямованості роботи з розвитку мовлення, яка надає дитині можливість спілкування з оточенням, здобуття та обміну інформацією, що надзвичайно важливо для іiі успішної соціалізації (Базовий компонент, 2021).

Н. Гавриш, одна зі співавторів Державного стандарту, вказує, що запропонований підхід до формування мовленнєвої компетентності дошкільника відповідає сучасним тенденціям у вітчизняній дошкільній лінгводидактиці, яка пріоритетним завданням визначає виховання, уже 3 перших років життя людини, здатної творчо й доречно використовувати засоби мови та мовлення в різних життєвих ситуаціях, зокрема презентувати себе, взаємодіяти з іншими, реалізувати свої потреби і наміри. Дослідниця пояснює, що саме такий підхід поєднує в собі навчання мови й розвиток мовленнєвих умінь і навичок, але чітко визначає особистісні пріоритети як мету й результат.

Важливий акцент Н. Гавриш робить на тому, що нині на першому плані має бути надання можливості дитині отримувати власний комунікативно-мовленнєвий досвід, активну практику самостійного й свідомого вирішення різних мовленнєвих завдань, а не лише наслідування зразка й відпрацювання окремих умінь (Гавриш, 2021).

Однак, як стверджують провідні фахівці в галузі дошкільної лінгводидактики: А. Богуш, Н. Гавриш, К. Крутій, сучасний стан розвитку мовлення старших дошкільників $є$ незадовільним. Деякі 3 них наводять досить невтішні цифри, а саме: у 85\% п’ятирічних дітей рівень мовленнєвого розвитку відповідає рівню трирічних малюків.

Причин такого стану речей багато. Зокрема, К. Крутій виокремлює такі негативні чинники, що впливають на мовленнєву функцію дошкільнят: погіршення стану здоров'я дітей; істотне звуження обсягу «живого» спілкування в сім’і; не розуміння батьків своєї функції - спілкування 3 дитиною має починатися у пренатальний період; глобальне зниження рівня мовної та мовленнєвої культури в суспільстві; недостатня увага педіатрів до мовленнєвого розвитку дитини. Дослідниця вважає, що помилково розглядати мовленнєвий розвиток як ізольований психічний процес у відриві від мислення, уяви, емоцій. Навчання мови, на думку К. Крутій, не повинно відбуватися лише в лінгвістичній площині, ігноруючи комунікативні вміння дітей. Робота 3 розвитку мовлення клопітка, щохвилинна, результату відразу не видно й тому, зазначає авторка, вихователі іноді не надто нею переймаються, а також орієнтуються на середній рівень мовленнєвого розвитку дитини й використовують у мовленнєвій роботі здебільшого фронтальні методи (Крутій, 2021).

К. Крутій вважає, що одним із важливих завдань сучасної дошкільної лінгводидактики $€$ вдосконалення програм і навчальних посібників із навчання мови й розвитку мовлення дітей.

Розв'язання проблеми мовленнєвого розвитку сучасних дошкільнят автор також бачить у використанні різних форм навчальної діяльності у закладі дошкільної освіти. К. Крутій вважає, що відмова від занять як основної форми навчання в закладі дошкільної освіти й використання лише ігрових форм роботи негативно позначаються на розвитку дітей і підготовці їх до школи. Важливо, аби заняття не перетворювалося в дидактичний каламбур як веселу, дотепну гру, після якої мало що залишається в голові, душі й серці дітей. Аналізуючи сучасні технології, що вже підкорили усі сфери нашого життя, в тому числі і дошкільну освіту, автор вдається до визначень найбільш уживаного терміну останніх років на теренах Internet - «педагогічний дизайн». На думку К. Крутій, найбільш доречним у системі дошкільної освіти буде використання педагогічного дизайну як процесу. Автор тлумачить педагогічний дизайн заняття як спланований i систематичний процес, що передбачає реалізацію чотирьох компонентів: предметно-просторового; пізнавально-діяльнісного; соціально-особистісного; рефлексивно-творчого.

Така модель заняття націлює на цікаву, творчу роботу з дітьми, що потребує від педагога глибокого роздумування над кожним кроком на занятті. Вихователь повинен розуміти, що важливо не просто зацікавити малюків, а й націлити їх на пошуки розв'язання проблемної ситуації, дошукування потрібного слова, надихнути до діяльності, під час якої можна навчитись, зрозуміти, переконатись, зробити висновки й захотіти йти далі (Крутій, 2012).

Проблему формування мовленнєвої компетенції як основи підготовки дітей дошкільного віку до навчання грамоти досліджувала С. Швидка. Авторка звертає увагу на особливості мовленнєвого розвитку дошкільників, вказуючи, що він починається 3 перших років життя. Саме тому важливо не пропустити той безцінний період, коли в дитини закладаються основи мислення і мовлення, коли вона відкрита до сприйняття нового, коли іiі свідомість незашлакована зайвим 
і непотрібним, коли вона прагне до спілкування і засвоєння життєвих цінностей (Швидка, 2018).

У процесі мовленнєвого розвитку дитина набуває мовленнєвих компетенцій, тобто, за визначенням А. Богуш, вміння адекватно i доречно, практично користуватися мовою в конкретних ситуаціях (висловлювати свої думки, бажання, наміри, прохання тощо), використовувати для цього як мовні, так і позамовні (міміка, жести, рухи) та інтонаційні засоби виразності мовлення. Критеріями мовленнєвої компетенції (за А. Богуш) є культура, правильність, адекватність, логічність, різноманітність, естетичність мовлення (Богуш, 2004).

На основі теоретичних розвідок та експериментального дослідження С. Швидка робить висновок про недостатній рівень мовленнєвого розвитку дітей старшого дошкільного віку. Діагностика рівнів мовленнєвого розвитку за допомогою Гейдельберзького тесту (адаптованого К. Крутій) дозволила встановити, що в старших дошкільників переважає середній (30\%), нижчий за середній $(20 \%)$ та низький $(20 \%)$ рівні мовленнєвого розвитку. Дослідниця зазначає, що це - свідчення необхідності пошуку ефективних шляхів мовленнєвого розвитку дошкільників, використання сучасних інноваційних підходів, що може значно підвищити ефективність процесу мовленнєвого розвитку дітей та оптимізувати процес підготовки ïх до навчання грамоти (Швидка, 2018).

Проблеми формування дошкільника-мовця торкаються дослідження В. Чекаліної, яка підкреслює важливе значення мовлення в становленні й життєдіяльності особистості. Дослідниця вважає, що на етапі дошкільного дитинства надто важливо, щоб дитина отримувала різнобічну допомогу в оволодінні багатим, правильним мовленням. Автор зазначає, що у період поширення масової культури велика увага приділяється вихованню мовної особистості, тобто такої, яка володіла б усіма виражальними засобами рідної мови, була б спроможна вільно виражати власні позиції, логічно й послідовно висловлювати свої думки, судження та переконання, пояснювати їх і доводити.

Аналізуючи ступінь оволодіння дітьми зв'язним монологічним мовленням, В. Чекаліна вказує на низку труднощів: дошкільникам важко скласти розповідь, втрачається зв'язність висловлювання, часто порушується структура розповіді, висловлювання насичене паузами, повторами, діти відхиляються від теми, значна частина дітей дошкільного віку взагалі не володіє зв'язним українським мовленням. Саме тому, наголошує вчена, виникає потреба в оновленні змісту, вдосконаленні форм, методів і технологій навчання дітей рідної мови, розвитку культури мовлення та мовленнєвого спілкування (Чекаліна, 2014).

Висновки. Отже, розвиток мовлення $\epsilon$ надзвичайно важливим для всебічного становлення особистості дошкільника. Однак сучасний стан розвитку мовлення дітей дошкільного віку часто $\epsilon$ недостатнім, що зумовлюється погіршенням здоров'я, звуженням обсягу «живого» спілкування в сім'ї. Свою роль відіграє й орієнтація вихователів на середній рівень мовленнєвого розвитку вихованців, використання в роботі з ними фронтальних методів.

Подолання проблем у розвитку мовлення дошкільнят науковці пов'язують із наданням вихованцеві можливості отримувати власний комунікативно-мовленнєвий розвиток, розширенням кола й інтенсивності його спілкування. Крім цього, варто вдосконалювати й роботу вихователів закладів дошкільної освіти, а також методичний супровід їхньої діяльності. Зокрема, постає необхідність в удосконаленні програм із навчання мови й розвитку мовлення дітей, урізноманітненні форм, методів і засобів навчання дітей рідної мови й розвитку культури мовлення.

Перспективами подальших досліджень може стати характеристика інноваційних технологій навчання мови, а також розвитку мовлення дітей дошкільного віку.

\section{СПИСОК ВИКОРИСТАНИХ ДЖЕРЕЛ}

1. Про затвердження Базового компонента дошкільної освіти (Державного стандарту дошкільної освіти) нова редакція : Наказ Міністерства освіти і науки України від 12 січня 2021 р. № 33 / Міністерство освіти і науки України. URL: https://mon.gov.ua/storage/app/media/rizne/2021/12.01/Pro_novu_redaktsiyu\%20Bazovoho\%20komponenta\%20 doshkilnoyi\%20osvity.pdf (дата звернення: 01.02.2021).

2. Богуш А. М. Мовленнєвий розвиток дітей від народження до 7 років : Монографія. Київ, 2004. 376 с.

3. Гавриш Н. В. Мовлення дитини. Впроваджуємо Базовий компонент дошкільної освіти (нова редакція). Дошкільне виховання. 2021. № 3. С. 3-8.

4. Крутій К. Л. Модерні практики розвитку мовлення дошколят в Україні та за кордоном : Вебінар. Освіта України : вебсайт. URL: https://www.ra-ou.com.ua/index.php?id=663 (дата звернення: 25.03 2021).

5. Крутій К. Л. Розвиток почуття мови у дітей засобами штучних текстів. Катерина Крутій : вебсайт. URL: http://ukrdeti.com/5.pdf (дата звернення: 25.04.2021). 
6. Крутій К. Л. Термінологічне поле дошкільної дидактики: дизайн, сценарій чи все ж таки конспект заняття? Дошкільна освіта. 2012. № 3. С. 4-12.

7. Швидка С. О. Сучасні методи підготовки дітей дошкільного віку до навчання грамоти. Вісник Черкаського університету. 2018. № 10-11. C. 112-117. URL: http://ped-ejournal.cdu.edu.ua/article/view/3201/3390 (дата звернення: 26.04.2021).

8. Чекаліна В. А. Формування мовленнєвої компетентності дошкільників у процесі навчання переказу літературних творів. Стандарти дошкільної освіти : дискурс науки і практики. Київ, 2014. С. 325-331. URL: https://elibrary.kubg.edu.ua/id/eprint/4579/1/V_Chekalina_04_14_PI.pdf (дата звернення: 08.12.2020).

\section{REFERENCES}

1. Bazovyj komponent doshkilnoyi osvity. 2021. [The basic component of preschool education. 2021]. URL: https://mon.gov.ua/storage/app/media/rizne/2021/12.01/Pro_novu_redaktsiyu\%20Bazovoho\%20komponenta\%20 doshkilnoyi\%20osvity.pdf (appeal date: 01.02.2021). [in Ukrainian].

2. Bogush A. M. Movlennyevy`j rozvy`tok ditej vid narodzhennya do 7 rokiv: Monografiya. [Speech development of children from birth to 7 years: Monograph] Kyiv, 2004. 376 p. [in Ukrainian].

3. Gavrysh N. V. Movlennya dytyny. Vprovadzhuyemo Bazovyj komponent doshkilnoyi osvity (nova redakciya). Doshkilne vyhovannya. [The child's speech. The introducing of the Basic component of preschool education (new edition). Preschool education.] 2021. Vol. 3. pp. 3-8. [in Ukrainian].

4. Krutij K. L. Vebinar Moderni praktyky rozvytku movlennya doshkolyat v Ukrayini ta za kordonom [Webinar Modern practices of speech development of preschool children in Ukraine and abroad] URL: https://www.ra-ou.com.ua/index. php?id=663 (appeal date: 25.03 2021). [in Ukrainian].

5. Krutij K. Rozvytok pochuttya movy u ditej zasobamy shtuchnyh tekstiv. [The development of children's sense of language by means of artificial texts.] URL: http://ukrdeti.com/5.pdf (appeal date: 25.04.2021). [in Ukrainian].

6. Krutij K. L. Terminologichne pole doshkilnoyi dydaktyky: dyzajn, scenarij chy vse zh taky konspekt zanyattya? Doshkilna osvita. [Terminological field of preschool didactics: design, script or a lesson outline? Pre-school education] 2012. Vol. 3. [in Ukrainian].

7. Shvydka S. O. Suchasni metody pidgotovky ditej doshkilnogo viku do navchannya gramoty. [Modern methods of preparing preschool children for literacy]. Bulletin of Cherkasy University. 2018. URL: http://ped-ejournal.cdu.edu.ua/ article/view/3201/3390 (appeal date: 26.04.2021). [in Ukrainian].

8. Chekalina V. A. Formuvannya movlennyevoyi kompetentnosti doshkilnykiv u procesi navchannya perekazu literaturnyh tvoriv. [Formation of speech competence of preschoolers in the process of learning to translate literary works.] Standards of preschool education: the discourse of science and practice. Kyiv, 2014. pp. 325-331. URL: https://elibrary.kubg.edu.ua/id/ eprint/4579/1/V_Chekalina_04_14_PI.pdf (appeal date: 08.12.2020). [in Ukrainian]. 